\title{
Tari Ritual dan Kekuatan Adikodrati
}

\author{
Mamik Suharti \\ Institut Seni Indonesia (ISI) Surakarta \\ Jl. Ki Hajar Dewantara No. 19 Kentingan Jebres, Surakarta 57126
}

\begin{abstract}
Ritual dance performing arts is closely related to its social, entertainment, aesthetic, even community rites in its presentation. The ritual function is fully covered by irrational things which means believes in supernatural forces, spirits, and the goddess that affect the life. Its belief is reflected in ritual dance performances of Tayub, Sintren, Bedaya Ketawang, Sang Hyang, and Seblang in Banyuwangi.
\end{abstract}

Keywords: ritual dance, supernatural

\begin{abstract}
ABSTRAK
Seni Pertunjukan tari ritual sangat berkaitan erat dengan sosial, hiburan, estetik, bahkan upacara-upacara masyarakat dalam pertunjukannya. Fungsi ritual sangat dipenuhi oleh hal-hal tidak rasional yang berarti kepercayaan pada kekuatan supranatural, roh-roh, dan dewa-dewa yang mempengaruhi kehidupannya. Kepercayaannya direfleksikan dengan pertunjukan tari ritual Tayub, Sintren, Bedaya Ketawang, Sang Hyang, dan Seblang di Banyuwangi.
\end{abstract}

Kata kunci: tari ritual, supranatural

\section{PENDAHULUAN}

Ketika tari diperbincangkan dalam konteks kehidupan manusia, permasalahan yang hendak dikaji sangatlah kompleks. Hal ini juga tidak lepas dari berbagai multi fungsi yang melekat pada seni pertunjukan tari dalam kehidupan manusia, baik secara individual maupun kelompok. Seni pertunjukan tari ritual dan kekuatan adikodrati merupakan seni pertunjukan tari ritual yang cukup banyak berkembang di Nusantara pada umumnya dan di pulau Jawa dan Bali pada khususnya. Kalau diperhatikan keberadaan seni pertunjukan ritual, terutama seni pertunjukan tari yang berhubungan dengan upacara, sangatlah unik untuk di- ketahui secara mendalam. Keunikan yang ada terletak pada bentuk seninya itu sendiri, yaitu seni pertunjukan tari tradisi baik yang hidup di pedesaan maupun yang ada di lingkungan keraton. Kekhasan yang dimilikinya juga terletak pada hal-hal yang berhubungan kekuatan gaib di luar batas kemampuan manusia pada umumnya, dan dihubung-hubungkan dengan roh-roh halus yang dipercayai terus berperan dalam kehidupan di dunia ini. Di samping itu yang sangat menarik adalah, bahwa jenis seni pertunjukan ini dimanfaatkan dan difungsikan dalam berbagai kepentingan dalam kehidupan masyarakat pendukungnya, misalnya saja sebagai penolak bala, penyembuhan penyakit, kesuburan lingkungan alam (tanah, 
air, tumbuh-tumbuhan), dan termasuk juga kesuburan manusia. Aspek-spek tersebutlah yang menjadi daya tarik penulis untuk memahami seni pertunjukan tari ritual dan kekuatan adikodrati yang melekat di dalamnya.

Mengingat masing-masing kehidupan pertunjukan tari dalam masyarakat pendukungnya memiliki peran dan fungsi yang berbeda-beda sesuai dengan kelompok etnis, lingkungan, kepercayaan, tatanan moral, serta latar belakang kehidupan masyarakatnya, maka semuanya itu akan berpengaruh pada bentuk dan fungsi pertunjukan yang ada. Seperti diungkapkan oleh Soedarsono, bahwa secara garis besar seni pertunjukan memiliki tiga fungsi primer, salah satunya adalah sebagai sarana ritual, yaitu bila penikmatnya adalah kekuatan-kekuatan yang tak kasat mata seperti misalnya dewa atau roh nenek moyang, maka seni pertunjukan berfungsi sebagai sarana ritual. (Soedarsono, 1999: 123).

Oleh sebab itu untuk mengkaji masalah tari yang berkaitan dengan kekuatan adikodrati perlu dilihat dari: bagaimana latar belakang pemunculannya, ragam-ragam bentuknya, dan bagaimana bentuk-bentuk kekuatan adikodrati dalam tari ritual yang masih dapat kita nikmati sampai sekarang. Seperti dikemukakan oleh Curt Sachs, bahwa fungsi tari secara garis besar mempunyai dua fungsi, yaitu untuk tujuan magis dan sebagai tontonan. Sebagai fungsi magis dimaksudkan untuk mempengaruhi keadaan dunia, manusia, serta lingkungannya, seperti hujan, kesuburan, sakit, kematian, percintaan, dan sebagainya (Curt Sachs, 1963: 60).

Seni pertunjukan tari ritual, yaitu seni pertunjukan Tari Tayub dan Sintren di Jawa Tengah, Tari Sang Hyang di Bali, Tari Bedhaya Ketawang di Keraton Surakarta, dan Tari Seblang di Banyuwangi Jawa Timur, dianalisis dengan menguraikan beberapa bentuk seni pertunjukan tersebut diharapkan ada pemahaman mengenai tari ritual terkait dengan konteksnya dalam kehidupan sehari-hari.

\section{Konsep Penyelenggaraan Ritual}

Tatanan moral dalam sebuah kehidupan masyarakat sangat menentukan sikap dan tindakan orang yang hidup dalam lingkungannya. Perubahan tatanan moral telah menimbulkan sikap-sikap menonjol bagi masyarakat kita, di antaranya adalah, bahwa dunia yang penuh dengan kekuatan hidup semua makhluk dan benda yang ada, seperti yang digambarkan oleh orang dengan pandangan 'dinamistis' dari kehidupan, menghendaki adanya upaya-upaya yang ajeg untuk mempertahankan keseimbangan potensi hidup yang benar lewat sarana-sarana magis.

Sebuah dunia yang dikuasai oleh kekuatan-kekuatan misteri yang tidak diketahui, oleh roh-roh serta jiwa nenek moyang seperti yang dibayangkan oleh orang yang masih berpandangan hidup animistis; mereka menghendaki adanya hidup damai dengan kekuatan-kekuatan ini. Diungkapkan oleh Edi Sedyawati bahwa, seni sebagai ekspresi perasaan manusia merupakan kebutuhan sesuai dengan perkembangan lingkungannya. Kehadiran seni bersama-sama manusia, pada mulanya merupakan dorongan atas kepercayaan akan adanya kekuatan adi kodrati di atas manusia. Barangkali tidak meleset jika dikatakan bahwa pada mulanya pendorong utama kesenian adalah religi yang disertai dengan upaya pencarian dan perumusan nilai-nilai keindahan (Edi Sedyawati, 1992: 9). Dalam konteks ini dijelaskan oleh Van Peursen, bahwa dalam hubungannya dengan upacara, tari memainkan peran yang sangat penting, karena daya-daya ilahi mempengaruhi penari yang lalu tak sadarkan diri, selanjutnya akan melindungi usaha yang hendak dilaksanakan dalam kehidupan. Bentuk ritual yang mencerminkan 
ekspresi estetis dan kepercayaan masyarakat akan kehadiran kekuatan adi kodrati, bertujuan untuk mempengaruhi roh agar tujuan dan kepentingan pelaku ritus terpenuhi (Van Peursen, 1976:40-41).

Pada masa lampau, kreativitas artistik yang telah mengabdi pada fungsi-fungsi ritual magis dan religius, telah memberi bentuk yang nyata pada mitos-mitos, serta telah meningkatkan kehidupan seremonial yang sekuler pada peristiwa-peristiwa penting dalam komunitas-komunitas kehidupan masyarakat. Kematian dan kesuburan adalah proses utama yang merangkum dan membentuk suatu kehidupan seni di sekelilingnya. Seni menyediakan pernyataan sah yang jelas pada penolakan manusia apabila dihadapkan pada fenomena kematian. Ketakutan akan kematian serta kepada yang telah mati, membuat yang telah mati 'hidup terus', karena rohnya masih dipercaya ada di sekitarnya.

Sementara itu dalam konteks kesuburan, seni tari merupakan benang merah yang menyambung dari rangsangan, keinginan, ketakutan, harapan, dan kegembiraan dalam kehidupan masyarakat agraris. Kebanyakan tarian masa lampau juga diasosiasikan dengan ritus, yang pada gilirannya dilihat sebagai ciri-ciri dari banyak aspek penting dalam kehidupan. Citra tentang orang masa lalu (primitif) adalah mereka yang dibebani dengan berbagai upacara, yang tak dimungkinkan memperoleh sesuatu, akan menari, dalam sebuah langkah tanpa upacara. Tarian yang berlaku bagi masyarakat ini pada umumnya merupakan representasi dramatik yang menggambarkan roh dan pahlawan yang sudah mati dipercaya benar-benar ikut ambil bagian dalam kehidupan mereka. Kesan tersebut bergantung pada keyakinan bahwa dengan menirukan tingkah dari seseorang atau binatang, pada tingkatan tertentu yang bersangkutan dirasuki oleh roh makhluk tersebut. Dengan menirukan tindakan yang ditunjukkan oleh pahlawan dan makhluk supranatural dari dunia roh, seseorang mungkin saja memperoleh sebagian dari kuasa misterinya (Anya Peterson Royce, 2007: 22).

Dilahirkan dari konsep kesuburan serta dilengkapi dengan ketrampilan, tari dari masa ke masa telah memperkokoh kehidupan perseorangan maupun masyarakat, terutama pada aspek-aspek religiusitasnya. Di dunia peradaban lama, tari adalah sebuah jampi-jampi pembebasan seperti nyanyian dan doa-doa. Tari mengiringi upacara-upacara sebagai aspek penting dari kehidupan dan dari kematian. Kemakmuran dan kesuburan dipresentasikan dengan tari-tari pada penanaman maupun permulaan siklus baru setelah panen. Demikian juga tari disajikan pada pesta-pesta transisi penting dari hidup, terutama perkawinan serta upacara kematian, serta dilakukan pada upacaraupacara bersih desa dan sejenisnya.

Bila kesuburan dan keamanan dipercaya sebagai perlindungan dari roh-roh nenek-moyang, dari kebajikan roh-roh alam, atau dari pemberian restu dewa-dewa yang agung, maka orang-orang menari adalah untuk mengambil hati serta menghormati mereka. Oleh karena itu, kelestarian kehidupan ditentukan pada kehadiran roh-roh nenek moyang yang melindunginya. Para penari seringkali kerasukan, hal ini dipercaya berhubungan dengan kekuatan-kekuatan yang lebih tinggi di luar batas kekuatan manusia. Kekuatan inilah yang sering disebut dengan kekuatan 'Adikodrati' atau kekuatan supernatural, karena kekuatan tersebut melebihi kekuatan kodrat manusia. Di sinilah taritari trance atau kerasukan (tak sadar diri) memainkan peranan penting dalam komunitas tertentu, sehingga seringkali taritari tersebut ditampilkan untuk 'melawan' bencana-bencana yang mengganggu dalam kehidupan. Di samping itu penari-penari yang trance benar-benar menikmati sebuah prestise, karena ketika kerasukan, mereka telah menjadi sarana kekuatan supernatural (Claire Holt, 2000: 125). 
Keragaman seni pertunjukan tari di Nusantara, yang pada umumnya tumbuh dan berkembang di daerah-daerah dalam komunitas masyarakat yang mayoritas berbudaya agraris dengan mata pencaharian bercocok tanam, serta yang masih melekat dengan pengaruh budaya Pra-Hindu, tetap melestarikan nilai-nilai masa lampau ini, termasuk seni pertunjukan tarinya sebagai peninggalannya. Di sini bisa dilihat dari adanya kenyataan bahwa para pendukung tarian terebut masih percaya dengan kekuatan gaib atau adikodrati dan kekuatan alam sekitarnya.

Dengan demikian seni pertunjukan tari yang bersifat trance atau kerawuhan dalam sebuah upacara ritual desa, sangat bermakna bagi masyarakat, karena tari tersebut tidak hanya mengejar prestasi artistik saja melainkan juga mengejar peran dan fungsi serta makna kehidupan yang merupakan tujuan utamanya. Peran dan makna itu di antaranya adalah bahwa tari dimanfaatkan untuk berbagai harapan yang berhubungan dengan konteks kehidupan, baik kehidupan manusia maupun kehidupan alam sekitarnya, termasuk tumbuh-tumbuhan dan binatang. Harapan-harapan itu sangat erat hubungannya dengan kesuburan tanaman pertanian masyarakat, kesuburan tanah, kesuburan binatang piaraannya, dan kesuburan masyarakat itu sendiri. Hal ini juga merupakan cermin masyarakat yang berperan sebagai perantara antara dunia manusia dengan kekuatan adi kodrati.

\section{PEMBAHASAN}

\section{Bentuk-Bentuk Tari Ritual}

Berkaitan dengan pertunjukan tari yang berhubungan dengan kekuatan adikodrati, dapat kita amati dari beberapa ragam tari rakyat yang masih hidup di berbagai daerah, untuk kepentingan-kepentingan ritual. Di antara tari rakyat tersebut adalah, Tari Sintren di Pekalongan, Tari Tayub di Blora dan Purworejo. Di Pulau Bali Tari Sang Hyang untuk kepentingan upacara masih tumbuh dengan baik, karena pertunjukan tari dan ritual merupakan kebutuhan integral. Demikian seni pertunjukan tari ritual yang diselenggarakan di Keraton Surakarta, menunjukkan hal-hal yang penuh dengan religio-magis dan kepercayaan roh halus (Kanjeng Ratu Kidul penghuni laut Selatan). Tari ritual Seblang dari Banyuwangi yang penuh diselimuti oleh sesuatu yang gaib dan sakral mencerminkan kehidupan masyarakat pendukungnya yang masih percaya adanya kekuatan adikodrati.

Pertunjukan tari ritual yang diselenggarakan oleh masyarakat pedesaan, pada umumnya justru yang menjadi tujuan utamanya adalah untuk menyampaikan pesan kepada masyarakat maupun sebagai tumpuan harapan dan sarana memohon perlindungan terhadap para leluhur, roh halus serta kepada Tuhan lewat aktivitas ritual. Dengan demikian simbolisme dalam masyarakat tradisional, di samping membawakan pesan-pesan kepada generasi berikutnya juga dilakukan dalam kaitannya dengan religi. Semuanya diungkapkan lewat sarana gerak atau tingkah laku, bunyi-bunyian, benda-benda, bau-bauan atau simbol-simbol yang tersaji dalam sebuah bentuk ritual dan seni pertunjukan (Budiono Herusatoto, 1983: 31). Dalam hal ini simbol sebagai salah satu penyederhanaan dari aspek-aspek dalam kebudayaan yang dipakai untuk penghubung dalam menguraikan atau melukiskan sesuatu. Di samping itu simbol juga merupakan pengantar terhadap pemahaman objek-objek, serta simbol adalah fenomena fisik yang mempunyai arti atau makna bagi penggunanya, tetapi juga tidak menutup kemungkinan untuk diinterpretasikan.

Beberapa fungsi seni pertunjukan dalam lingkungan-lingkungan etnik di Indonesia dapat disebutkan sebagai berikut: sebagai pemanggil kekuatan gaib, sebagai penjem- 
put roh-roh pelindung untuk hadir di tempat pemujaan, untuk memanggil roh-roh baik serta mengusir roh-roh jahat, untuk memperingati nenek moyang dengan menirukan kegagahan maupun kesigapannya, atau juga sebagai pelengkap upacara sehubungan dengan peringatan tingkat-tingkat hidup seseorang, sebagai pelengkap upacara sehubungan dengan saat-saat tertentu dalam perputaran waktu, atau sebagai perwujudan dari dorongan untuk mengungkapkan keindahan semata (Edi Sedyawati, 1981: 53).

Beberapa pertunjukan tari yang berkait dengan kepentingan ritual sejak kemunculannya tampak erat hubungannya dengan halhal yang bersifat tidak kasat mata, di mana tarian ini difungsikan untuk berhubungan dengan dunia roh halus, seperti pemanggilan roh-roh pelindung untuk berbagai kepentingan dalam kehidupan. Beberapa pertunjukan tari ritual di Jawa Tengah yang sampai sekarang masih hidup, Tari Sintren misalnya, merupakan salah satu tari rakyat yang berkembang di pesisir pantai utara pulau Jawa, khususnya pantai utara Jawa Tengah. Peninggalan kebudayaan pra-Hindu ini masih tampak lekat dalam Tari Sintren sampai sekarang, yang dapat diketahui dari adanya (medium) dalam pertunjukannya. Saman adalah orang yang menyediakan tubuhnya sebagai medium untuk dimasuki roh halus guna keperluan sesuatu yang berkaitan dengan kehidupan. Hal ini dimaksudkan sebagai sarana menciptakan suasana gaib agar seorang penari atau saman dapat menghadirkan roh dan merasuk ke dalam dirinya, agar kemudian dapat merasuk ke dalam penari Sintren. Di sinilah kemudian pelaksanaannya disertai dengan bau-bauan yang berupa asap kemenyan dan minyak wangi, bunyi-bunyian atau suara musik, dan syair lagu atau nyanyi-nyanyian dari pemanjak, dengan disertai mantra-mantra dari seorang pawang (Willy Hanto, 1995: 4243).
Dari pertunjukan Sintren tersebut, dapat dimaknai bahwa kepercayaan manusia terhadap makhluk halus dan kekuatan adikodrati/supernatural untuk mengendalikan sesuatu dengan cara religi sangat diyakini. Perilaku ritual ini sangat tampak apabila manusia tidak dapat mengatasi dengan cara-cara lain. Tindakan upacara religius ini merupakan bagian penting bagi masyarakat pendukungnya yang bertujuan sebagai penghormatan kepada makhluk yang tak kasat mata ini. Diungkapkan oleh Sal Murgiyanto, bahwa kelalaian penghormatan kepadanya dapat mengganggu kesejahteraan dan perdamaian masyarakat yang bersangkutan; inilah bentuk komunikasi dengan Tuhan, maupun dewa dan roh-roh halus yang diyakini sebagai leluhurnya. Salah satu roh yang sangat diyakini dan berpengaruh bagi masyarakat pesisir utara adalah Dewi Lanjarsari dan Dewi Rantam Sari, sebagai penghuni laut utara. Pertunjukan ritual Sintren yang diselenggarakan oleh komunitas masyarakat petani ikan atau nelayan, banyak berharap kepada Dewi Lanjarsari dan Rantam Sari agar tangkapan ikan dapat melimpah, serta mendapatkan keselamatan selama ada di laut. Semuanya itu dilakukan melalui prosesi ritual pertunjukan Sintren. Tari Sintren selain berkaitan dengan pertanian juga sebagai sarana penyembuhan penyakit, sebagai penolak bala dan gangguan dari rohroh jahat (Hadi Subagyo, 2008: 188-189).

Hal ini tidak jauh berbeda dengan pertunjukan ritual Tayub yang berkembang di Jawa Tengah, khususnya di Kabupaten Blora dan di Kabupaten Purworejo. Pertunjukan Tari Tayub untuk kepentingan ritual bersih desa dilakukan secara musiman. Kehadiran Tari Tayub dalam komunitasnya memiliki multi fungsi, yaitu sebagai ritual, hiburan pribadi, sajian estetis, dan untuk kepentingan sosial. Dalam fungsinya sebagai ritual, tayub berperan sebagai dhukun, sebagai persembahan leluhur, hiburan roh halus, dan sebagai simbol kesuburan. Khususnya 
ritual tayub yang dilakukan oleh masyarakat Jogowangsan Kabupaten Purworejo, tayub diyakini sebagai penjelmaan dhanyang setempat. Dengan demikian hadirnya tayub dalam ritual, berarti hadirnya juga dhanyang atau leluhurnya, bahkan lebih dari itu penari tayub yang dinilai sebagai ledhek, dianggap orang mempunyai kekuatan yang bisa berhubungan dengan alam gaib (memiliki kekuatan di luar kemampuan manusia) dan sebagai media penyembuhan atau pengobatan penyakit serta permohonan untuk segala keperluan. Menurut Levi-Straus, $d h u-$ kun adalah orang yang ahli dalam menyembuhkan penyakit yang disebabkan kekuatan batin adikodrati dan kekuatan-kekuatan gaib (Sutarno Haryono, 2002: 32-35). Demikian juga ritual Bersih Desa di Kabupaten Blora, yang diungkapkan oleh Sri Rochana Widyastutiningrum dalam bukunya yang berjudul Tayub Di Blora Jawa Tengah Pertunjukan Ritual Kerakyatan, menjelaskan bahwa masyarakat Blora, meskipun mayoritas beragama Islam, akan tetapi masih ada yang percaya terhadap kekuatan gaib yang merupakan peninggalan kebudayaan animisme dan dinamisme. Sebagai masyarakat petani, mereka masih memegang adat-istiadat yang diwariskan oleh nenek moyangnya, yakni mempercayaai adanya kekuatan gaib atau supranatural yang menjaga padi dan petani yang mereka sebut Dewi Sri (dewi kesuburan). Oleh karena itu pertunjukan tayub sebagai bagian dari upacara ritual yang terkait dengan ritus kesuburan masih dilaksanakan dalam upacara bersih desa atau Sedekah Bumi yang dilaksanakan satu kali pada setiap tahun (2007: 61).

Bentuk dan jenis pertunjukan tari dalam konteks kemasyarakatan mempunyai kelompok-kelompok pendukung tertentu. Demikian juga kesenian dan aktivitas masyarakat bisa mempunyai fungsi dan makna yang berbeda. Perubahan fungsi, makna, dan perubahan bentuk dapat disebabkan oleh dinamika masyarakat yang bersang- kutan. Kesenian dan upacara ritual merupakan salah satu perwujudan kebudayaan yang juga mempunyai peran tertentu dalam masyarakat yang menjadi ajangnya.

Tari ritual dan kekuatan adikodrati, tidak hanya tumbuh dan berkembang pada komunitas masyarakat pedesaan saja, akan tetapi juga hidup dan berkembang di lingkungan keraton, khususnya di Keraton Kasunanan Surakarta. Genre Tari Bedhaya Ketawang sebagai induk Tari Bedhaya berikutnya, merupakan tarian sakral yang dewasa ini masih dapat kita nikmati satu tahun sekali dalam rangka ulang tahun jumenengan, sekaligus sebagai legitimasi eksistensi raja dan sebagai pusaka di keraton Kasunanan Surakarta.

Tari Bedhaya Ketawang di Keraton Surakarta ini diyakini sebagai curahan cinta suci Kanjeng Ratu Kidul Kencana Sari kepada Panembahan Senopati beserta keturunannya. Hal ini merupakan manifestasi keyakinan mereka pada alam gaib yang divisualisasikan dalam kesusastraan suci yang berupa sindhenan pada gendhing Semang-Semang. Tari Bedhaya Ketawang juga merupakan suatu sistem ritus dan upacara dalam religi lewat tindakan kebaktian terhadap Tuhan, roh-roh nenek moyang, atau mahkluk halus lain sebagai penghuni alam gaib lainnya. Di samping itu sistem ritus dalam Tari Bedhaya Ketawang, terwujud pada tindakan atau perilaku sembilan penarinya. Mereka harus melaksanakan aturan yang telah ditentukan yaitu caos dhahar, sebagai manifestasi dari kebaktian dan komunikasinya dengan mahluk halus dan dunia gaib (Nora Kustantina Dewi, 2002: 69-72).

Di daerah lain seperti di Bali, genre yang memiliki akar masa lalu adalah serangkaian tari yang disebut Sang Hyang, yang jenisnya kebanyakan dapat ditemukan di daerah pedesaan di pegunungan utara dan timur pulau Dewata. Semua tarian itu menempatkan seorang penari atau lebih menjadi kesurupan untuk menerima rasukan dewa-dewa atau binatang melalui pembakaran dupa, 
nyanyian, dan doa-doa. Setelah kemudian dirasuki roh dewa atau binatang, penari akan berinteraksi dengan penonton. Sang Hyang Dedari, salah satu Tari Sang Hyang yang paling dikenal, menunjuk adanya kesamaan pada penari-penari wanita muda bak bidadari yang merupakan setengah dewi dalam mitologi Hindu. Tarian ini digelar untuk waktu yang tidak pasti, karena dibutuhkan hanya jika ada malapetaka atau wabah penyakit. Secara tradisional, tarian yang dilakukan oleh gadis berumur sekitar sembilan sampai tiga belas tahun ini, dipertunjukkan pada malam hari, dan dimulai di halaman paling suci (jeroan) dari pura utama desa.

Ketika penari Sang Hyang sudah tak sadarkan diri atau kerasukan, dengan mata tertutup mereka menari bergoyang ke kanan-kiri dan mundur yang dibantu oleh wanita lebih tua yang berada di belakangnya. Selanjutnya pemangku meminta penari untuk berbicara, yang dengan gemetar mereka menyanyi dan kata-kata mereka ditujukan kepada orang-orang desa sebagai berikut. "Jangan takut pengikutku, kami datang sekarang, obat untuk penyakit kalian sudah di tangan".

Pemangku memimpin arak-arakan dan setelah penari meninggalkan jeroan, mereka di bawa ke seluruh sudut desa dan di tengah persimpangan jalan, untuk membuat gerakan menolak setan-setan yang menyebabkan wabah, sementara sang pemangku memercik-mercikkan air suci, untuk menyucikan desa. Akhir dari arak-arakan, penari dibawa kembali ke dalam pura, yang selanjutnya dibebaskan dari kondisi kerasukan dengan bantuan air suci dan doa-doa. Demikian juga dengan tari ritual Sang Hyang yang lainnya, seperti Sang Hyang Jaran, Sang Hyang Bojog, Sang Hyang Celeng, dan tarian ritual yang lain. Tarian tersebut dipertunjukkan untuk kepentingan yang berkaitan dengan hal-hal yang sifatnya melindungi masyarakat pendukungnya, seperti pengobatan penyakit, pengusiran roh-roh jahat, penolak wabah penyakit, dan bencana-bencana lainnya (Bandem, 2004: 15-21).

Dalam melaksanakan ritual tari, masyarakat tampaknya memiliki alasan, di antaranya agar pertaniannya selamat dan subur, rakyatnya terhindar dari petaka atau penyakit, keadaan desanya tenteram, atau untuk kepentingan hiburan, untuk meningkatkan rasa persaudaraan antar warga, dan sebagai upaya pencarian dan perumusan nilai-nilai keindahan. Dari alasan-alasan tersebut kiranya masyarakat berkepentingan untuk melaksanakan ritual secara rutin maupun pada saat-saat tertentu dengan penuh keyakinan dan sungguh-sungguh. Berkaitan dengan kepentingan itu, mereka berusaha untuk mendukung semua kebutuhan yang diperlukan dalam upacara ritual tersebut, baik yang bersifat materi maupun spiritual. Di samping itu masyarakat rela menyumbangkan tenaganya sampai berhari-hari selama upacara berlangsung tanpa imbalan jasa yang setimpal.

Begitu pula mengenai mitos yang berupa tari, bagi masyarakat pendukungnya dipandang mempunyai makna tersendiri sebagai simbol-simbol dalam kehidupan. Demikian dengan tingkah laku ritual yang telah mendarah-daging, sulit untuk ditinggalkan bagi masyarakat bersangkutan, karena tari ritual tersebut dirasakan memiliki kekuatan gaib yang bermakna bagi kehidupan masyarakat dan dipandang sebagai sesuatu yang keramat.

Semua tindakan atau motivasi yang dilakukan oleh masyarakat dalam ritual, adalah suatu sistem upacara religius yang bertujuan untuk mencari hubungan manusia dengan Tuhan, Dewa atau Dewi, dan mahkluk halus yang mendiami alam gaib. Sistem upacara religius ini adalah simbol dari ide yang terkandung dalam sistem kepercayaan. Seluruh sistem ritual itu terdiri dari aneka macam upacara yang merupakan tata laku yang telah mentradisi dalam kehidupan masyarakat pendukungnya. Ritus 
tersebut terdiri dari berbagai macam unsur seperti berdoa, bersujud, bersesaji, berkorban, makan bersama, menari, menyanyi, dan berprosesi. Maksud dan motivasi diselenggarakannya sebuah pertunjukan tari ritual ini, juga disebabkan karena adanya keyakinan serta ketakutan manusia akibat merasa tidak mampu mengatasi masalahnya lewat tindakan-tindakan rasional. Untuk itu manusia mengalihkan kepada kepercayaan akan perlindungan terhadap kekuatan-kekuatan adikodrati yang mengatur alam dan kehidupan manusia.

Di Kecamatan Glagah Kabupaten Banyuwangi Jawa Timur, dua bentuk pertunjukan budaya Tari Seblang yang hidup di desa Olehsari dan Bakungan menunjukkan begitu kompleksnya masyarakat yang masih mempercayai hal-hal yang bersifat gaib melalui pertunjukan tari. Tari Seblang yang merupakan salah satu tarian di Banyuwangi sebagai peninggalan kebudayan Pra-Hindu masih tampak melekat sampai sekarang. Salah satu cirinya adalah kepercayan manusia kepada makhluk halus dan kekuatan supranatural untuk mengendalikan sesuatu dengan menggunakan sarana religi apabila manusia tidak dapat mengatasi kegelisahannya dengan cara-cara lain. Tindakan upacara religius bagi masyarakat Olehsari maupun masyarakat desa Bakungan merupakan bagian yang sangat penting, dan merupakan kegiatan upacara bersih desa dengan acara pokok pertunjukan Tari Seblang. Hal ini dilakukan dengan tujuan penghormatan kepada sesuatu yang tidak tampak atau roh halus sebagai cikal bakal mereka yang diyakini memiliki kekuatan adikodrati dan sangat mempengaruhi dalam kehidupan msyarakatnya. Selain itu juga merupakan wahana komunikasi dengan Tuhan dan leluhurnya.

Dalam kaitannya dengan religi, Koentjaraningrat menjelaskan bahwa, religi mengandung bayangan orang akan wujudnya dunia gaib yang merupakan sistem keper- cayaan, yaitu tentang wujud-wujud makhluk halus dan kekuatan sakti. Untuk menghadapinya manusia mengekspresikannya dalam berbagai macam bentuk yaitu: khawatir, cinta, hormat, bakti, dan takut (Koentjaraningrat, 1990: 240-241). Munculnya perasaan-perasaan tadi akan mendorong manusia untuk melakukan berbagai perbuatan yang bertujuan mencari hubungan dengan dunia gaib, sehingga akan melahirkan aktivitas ritual.

Berkaitan dengan upacara bersih desa di Olehsari dan Bakungan, dalam pelaksanaannya tak bisa lepas dari seni. Seni pertunjukan Tari Seblang yang pada mulanya berfungsi sebagai upacara selamatan desa agar terhindar dari segala petaka, sampai sekarang masih tetap difungsikan, walaupun kenyataannya mengalami perubahan dan penambahan fungsi sejalan dengan dinamika kehidupan masyarakat kedua desa tersebut.

Upacara Seblang diyakini oleh masyarakat sebagai upacara yang keramat. Hal ini dapat diamati dari proses awal dalam menentukan segala sesuatu yang berkaitan dengan waktu, tempat, pelaku, maupun prasarana upacara. Berkaitan dengan pelaku, khususnya penari, getaran emosi keramat sangat terasa ketika para dukun dan kerabat penari Seblang, serta tokoh masyarakat berdialog dengan orang yang kejiman, dalam menentukan keturunan Seblang untuk menari pada sebuah upacara. Demikian jua dengan penentuan waktu dan tempat, perlu disepakati oleh warga atas restu dari roh halus, sehingga diyakini akan membawa berkah bagi masyarakat pendukungnya. Semua itu dilakukan agar upacara ritual yang dilaksanakan dijauhkan dari petaka yang mengancam kesejahteraan hidup.

Upacara Seblang apabila diamati secara teliti, memiliki multi fungsi dalam kehidupan, yaitu untuk kepentingan sosial, kepentingan hiburan, santapan estetis, dan yang utama untuk kepentingan ritual. Hal yang 
terakhir ini sangat erat hubungannya dengan keyakinan dan kepercacaan masyarakat mengenai hal-hal unik yang berkaitan dengan kekuatan adikodrati, yaitu Seblang sebagai sarana bersih desa, Seblang sebagai sarana kesuburan, Seblang sebagai sarana pengobatan penyakit, Seblang sebagai sarana penghormatan leluhur, dan Seblang sebagai sarana hiburan roh halus.

Sebagai sarana selamatan desa, telah mentradisi dalam kehidupan masyarakat di desa Olehsari maupun di desa Bakungan Banyuwangi, selamatan tersebut dirasakan sangat penting dan dinilai keramat. Oleh karena itu masyarakat berkewajiban untuk menyelenggarakan ritual setiap satu tahun sekali; untuk desa Olehsari pada bulan Jawa Syawal selama satu pekan, sedangkan di desa Bakungan pada bulan Besar selama satu hari. Jika selamatan ini tidak diselenggarakan, maka masyarakat akan diselimuti kekhawatiran. Koentjaraningrat menjelaskan bahwa: untuk mengadakan upacara selamatan diputuskan berdasarkan suatu keyakinan dan adanya perasaan kekhawatiran akan hal-hal yang tidak diinginkan (Koentjaraningrat, 1990: 347). Dengan diselimuti rasa khawatir tersebut, maka masyarakat akan patuh untuk melaksanakan selamatan desa secara rutin.

Mereka melaksanakan upacara selamatan desa juga bertujuan untuk memohon kepada penguasa alam agar desa seisinya dijauhkan dari berbagai petaka yang mengancam kesejahteraan hidup masyarakat. Di samping itu agar diberikan berkah, keselamatan, jauh dari penyakit, dan segala macam harapan akan kesejahteran hidup yang lain (Sal Murgiyanto, dan AM, Munardi, 1990: 16-17). Dengan menari mengelilingi desa, di perempatan jalan, di sudut-sudut desa, di sendang, kantor kalurahan, dan di kuburan pada hari terakhir, masyarakat percaya bahwa penari Seblang telah mengusir dan membersihkan roh-roh jahat di desa Olehsari.
Interaksi dan komunikasi antara masyarakat dan penari Seblang yang berkaitan dengan kepercayaan kekuatan adikodrati juga dapat diamati ketika penonton minta penyembuhan penyakit maupun minta doa restu, yaitu dengan cara menyerahkan air putih kepada penari. Kemudian penari memberi jampi-jampi atau doa pada air tersebut yang kemudian ditambahi dengan dimasukannya bunga yang dipetikkan dari mahkotanya (omprok). Selanjutnya air tersebut diminum oleh pemohon. Acara pengobatan juga terjadi ketika upacara siraman, pada kesempatan ini air untuk siraman dimanfaatkat untuk mandi maupun untuk mencuci muka agar sembuh dari penyakit dan menjadikannya awet muda. Bekas omprok penari bagi masyarakat pendukungnya diyakini dapat bermanfaat untuk menyuburkan tanah atau sawahnya, yaitu dengan cara memendam omprok tersebut di sudut-sudut sawah maupun di tanah pekarangannya. Di samping itu bekas omprok juga dipercaya untuk menjaga atau menghilangkan gangguan roh jahat yang ada di rumahnya.

\section{PENUTUP}

Dari uraian tentang tari ritual Sintren di Pekalongan dan Tari Tayub di Jawa Tengah, Tari Sang Hyang di Bali, Tari Bedhaya Ketawang di Keraton Surakarta, dan Tari Seblang di Banyuwangi Jawa Timur, masing-masing mempunyai kekhasan, keunikan, keindahan, dan tata cara yang berbeda, walaupun keragaman tari tersebut masih sarat dengan kekuatan adikodrati. Keunikan ini dapat di-lihat dari gerak tarinya, tata busananya, pola lantainya, maupun musik tarinya. Hal ini juga terlihat karena tarian tersebut merupakan interaksi dan komunikasi antara manusia dengan yang gaib atau kekuatan adikodrati, serta faktor kelangkaannya. Diamati dari bentuk fisik maupun bentuk dinamiknya, masing-masing merupakan 
ekspresi estetik dan simbolik dari komunitas pendukungnya lewat gerak maupun elemen-elemen pendukung, yang menyampaikan kesan maupun pesan yang berbeda antara tari ritual yang satu dengan yang lain.

Memperhatikan tata cara dari penyajian tari ritual tersebut masing-masing etnis mempunyai tata cara yang berbeda-beda, baik dari persyaratan atau perlengkapan untuk sesaji maupun tahapan-tahapan yang harus dilakukan. Dari pemilihan penari, pemilihan, pawang atau sesepuh diperlukan persyaratan-persyaratan khusus, demikian pula mengenai penentuan waktu maupun tempat. Dari uraian ini, pelaksanaan seni pertunjukan ritual bagi masyarakat, semuanya bermuara pada harapan-harapan dari masyarakat pendukungnya kepada Tuhan, kekuatan adikodrati, maupun roh penjaga alam (yang mereka percayai) agar masyarakat selamat terhindar dari petaka, menjadi tenteram, alamnya subur, dan berbagai harapan dalam kehidupan mereka terkabul.

\section{Daftar Pustaka}

Budiono Herusatoto

1983 Simbolisme dalam Budaya Jawa. Yogyakarta: Penerbit PT. Hanindita.

Edi Sedyawati

1992 "Sistem Kesenian Nasional Indonesia" Pidato Pengukuhan Jabatan Guru Besar Tetap Fakultas Sastra Universitas Indonesia di Jakarta.

1981 Pertumbuhan Seni Pertunjukan. Jakarta: Penerbit Sinar Harapan

Hadi Subagyo

2008 "Perubahan Bentuk dan Fungsi Pertunjukan Sintrèn dalam Kehidupan
Sosial Masyarakat Boyongsari Pekalongan" dalam Jurnal Dewaruci Pengkajian dan Penciptaan Seni.

Holt, Claire

2000 Melacak Jejak Perkembangan Seni Di Indonesia. Alih bahasa R.M. Soedarsono. Yogyakarta: Masyarakat Seni Pertunjukan Indonesia.

I Made Bandem

2004 "Kaja dan Kelod Tari Bali dalam Transisi", karangan Fredrik Eugene deBoer. Yogyakarta: Badan Penerbit Institut Seni Indonesia.

Koentjaraningrat

1990 Beberapa Pokok Antropologi Sosial. Jakarta: Dian Rakyat.

Nora Kustantina Dewi

2002 "Religio Magis dan Makna Simbolis Tari Bedhaya Ketawang", dalam Greget Jurnal Pengetahuan dan Penciptaan Tari, Jurusan Tari STSI Surakarta.

Peterson Royce, Anya

2007 Antropologi Tari, Terj. F.X. Widaryanto. Bandung: Sunan Ambu Press.

Peursen, C.A. Van

1976 Strategi Kebudayaan. Alih bahasa Dick Hartoko. Yogyakarta: Yayasan Kanisius.

R. M. Soedarsono

1999 Seni Pertunjukan Indonesia dan Pariwisata. Bandung: Masyarakat Seni Pertunjukan Indonesia.

Sal Murgiyanto dan Munardi

1990 Seblang dan Gandrung Dua Bentuk Tari Tradisi di Banyuwangi. Jakarta: Pembinaan Media Kebudayaan.

Sri Rochana Widyastutieningrum 2007 Tayub Di Blora Jawa Tengah Pertunjuk- 
an Ritual Kerakyatan. Surakarta: ISI Press.

Sutarno Haryono

2002 "Penari Tayub Sebagai Dukun dalam Ritus Bersih Desa Di Jogowangsan, Purworejo, Jawa Tengah", dalam Greget Jurnal Pengetahuan dan Pen- ciptaan Tari, Jurusan Tari STSI Surakarta.

Willy Hanto dkk.

1995 "Sintrèn Kesenian Rakyat yang Semakin Ditinggalkan Pendukungnya". Laporan Penelitian Kelompok, STSI Surakarta. 